\title{
Toward a Flipped Classroom Instructional Model for History education: A Call for Research
}

\author{
Chung Kwan Lo
}

\begin{abstract}
Some students are disengaged in learning History because of heavy workload of reading and writing requirement. Recently a few teachers have attempted to use flipped classroom (or inverted classroom) in their History classes to engage their students. The purpose of this paper is to identify some good practices in the existing literature of flipping the History classroom. However, there is hitherto a scarcity of research on flipped classroom in the contexts of History education, in which only five journal publications could be found. While researchers gave descriptions of their out-of-class and in-class learning activities, most of their flipped classrooms were not grounded in an established framework of instructional design. Based on the voices of the History teachers and students as well as the existing literature, I suggest using the $5 \mathrm{E}$ instructional model to guide the design of History flipped classroom. While this paper lays the groundwork for developing a $5 \mathrm{E}$ flipped classroom model, more empirical studies are needed to investigate the efficacy and challenges of this instructional design.
\end{abstract}

Index Terms-5E instructional model, flipped classroom, History education, review of research.

\section{INTRODUCTION}

Some students are disengaged in the teaching and learning activities of History courses. For example, Joseph [1] surveyed 415 secondary school students and found that students generally disliked the heavy workload of reading, writing, and memorizing requirement of their History classes. In particular, too much reading led to a negative impact on student attitude toward this subject. Although students might not describe History as a boring subject, majority of them refused to study History in their post-secondary education. In higher education contexts, Murphree [2] observed that the substantial amount of writing discouraged students from taking History courses as an elective or general education course. However, studying History is important since it enables students to gain insights into the past and develop critical thinking skills. So how can we improve the instructional approach of History education?

According to Joseph [1], interactive class activities were the most favorable aspect of History classes. Indeed, even novice History teachers recognized that group or collaborative work was one of the effective approaches of teaching History [3]. However, in a traditional classroom setting, the in-class time is usually dominated by teachers' direct lecturing. The use of group activities is minimal due to time constraint. Meanwhile, without the help of teacher and peers at home, writing assignments may become an unfavorable task [2].

In this regard, there is a growing interest in using flipped classroom instructional approach in various educational settings (see [4-7] for a review). As Bishop and Verleger [4] defined, flipped classroom consists of two components: (1) Direct computer-based individual instruction outside the classroom; and (2) interactive group learning activities inside the classroom. In the out-of-class learning component, students first explore the online learning resources (e.g. text-based materials and instructional videos) prepared by teachers. Students can acquire some basic knowledge about a particular topic before the face-to-face lesson. Shifting teachers' direct instructions outside the classroom thus frees up the in-class time for more interactive learning activities such as group discussion and small-group tutoring [8].

Before flipping a course, meta-studies or systematic reviews of existing literature can help practitioners gain insight into the design and implementation of flipped classroom [9]. However, the published reviews of flipped classroom research appear to be limited when adopting to the contexts of History education. For example, some review papers focused only on higher education [5], Asian universities [6], or other subjects such as nursing education [7]. Other papers reviewed the studies which might not be published in peer-reviewed journals (e.g., [4]). Therefore, conducting a review on how History teachers design their flipped classroom and the effectiveness of their intervention can help contribute to the knowledge of History education.

\section{PURPOSE OF THIS REVIEW}

Current studies of flipped classroom seldom explicate a conceptual framework of designing their instructional approach [4], [9]. In this regard, this paper reviews the published studies in the contexts of History education. Based on the voices of History teachers and students, this paper aims to propose a tentative instructional model of History flipped classroom. The following research questions were posed to guide the review:

1) How do the History teachers design their flipped classroom?

2) What are the effects, benefits, and challenges of flipping the History courses?

3) How can these studies inform the design and implementation of History flipped classroom?

\section{METHODS}

The process of selecting relevant literature followed the 
Preferred-Reporting of Items for Systematic Reviews and Meta-Analyses statement (PRISMA) [10]. In order to be as comprehensive as possible, the following 10 electronic databases were searched: (1) Academic Search Complete, (2) Academic Search Premier, (3) America: History \& Life, (4) British Education Index, (5) ERIC, (6) Historical Abstracts, (7) Library, Information Science \& Technology Abstracts, (8) MAS Ultra - School Edition, (9) Teacher Reference Center, and (10) TOC Premier. The search terms used in this review were as follows: ("flip*" OR "invert*") AND ("class*" OR "learn*") AND History. In this way, all other verb forms of "flip" (i.e., flipped and flipping) and "invert" (i.e., inverted and inverting) were included.

TABLE I: INCLUSION AND EXCLUSION CRITERIA FOR SELECTION

\begin{tabular}{lll}
\hline \hline & Inclusion criteria & Exclusion criteria \\
\hline 1. & $\begin{array}{l}\text { The studies must involve History } \\
\text { flipped classroom in any } \\
\text { educational contexts. }\end{array}$ & $\begin{array}{l}\text { The studies that were outside } \\
\text { History education. }\end{array}$ \\
The studies must report empirical & $\begin{array}{l}\text { The studies that were not } \\
\text { empirical research. }\end{array}$ \\
findings. & $\begin{array}{l}\text { The studies must be published in } \\
\text { Thelish. }\end{array}$ & $\begin{array}{l}\text { The studies that were not } \\
\text { written in English. }\end{array}$ \\
The studies must be published in & $\begin{array}{l}\text { The studies that were not peer } \\
\text { reviewed. }\end{array}$ \\
\hline \hline
\end{tabular}

Inclusion and exclusion criteria of selecting studies were developed (Table I). First and foremost, the studies must involve at least one History flipped classroom. Research contexts such as location of study and course level were flexible. Second, in order to analyze the efficacy of History flipped classroom, the studies must be an empirical research reporting student learning outcomes, student perceptions, or teacher perceptions. Finally, the studies must be written in English and published in peer-reviewed journals.

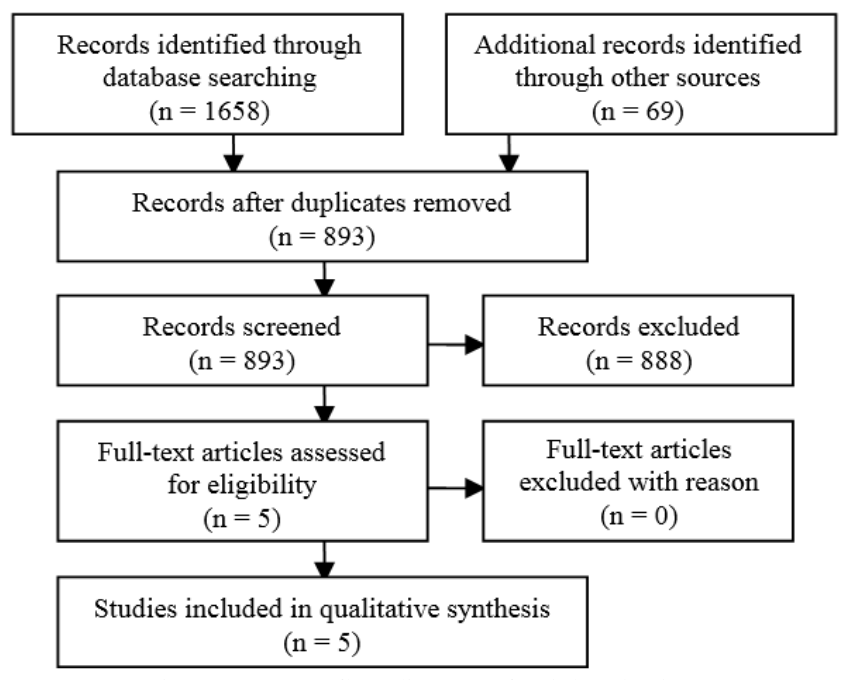

Fig. 1. PRISMA flow diagram of article selection.

By using the search terms, a total of 1658 peer-reviewed journal articles was found as of the end of June 2016. However, a large number of articles were removed because of a replication across databases. Also a large number of articles were found to be irrelevant after reviewing the abstract, particularly those were not related to teaching and learning. After the selection process, five articles were yielded. Full text version of these articles were retrieved from databases.
In view of a paucity of studies recruited, a snowballing procedure was executed by tracking the reference lists of all recruited articles [11]. A further 69 articles were then identified but these articles either duplicated with the search results or did not match the criteria of inclusion (e.g., published in peer-reviewed journals). Finally, this review proceeded with an in-depth qualitative synthesis on the recruited articles. Fig. 1 outlines the process of article selection.

\section{RESULTS}

Guided by the above mentioned inclusion and exclusion criteria, five studies were identified to be relevant to the research topic (i.e., flipped classroom in the contexts of History education). As shown in Table II, all the studies were conducted in the United States, ranging from secondary to higher education level. The curriculum of the History courses involved were diverse. The results revealed a notable lack of literature in the contexts of History education and also an absence of empirical studies in the non-U.S. environment.

\begin{tabular}{|c|c|c|}
\hline Study & Participant (location) & Course content (duration) \\
\hline Gaughan [12] & $\begin{array}{l}36 \text { undergraduates used } \\
\text { FC (USA). }\end{array}$ & $\begin{array}{l}\text { A World History course on } \\
\text { world civilization to } 1100 \\
\text { C.E. ( } 1 \text { semester). }\end{array}$ \\
\hline Murphree [2] & $\begin{array}{l}106 \text { undergraduates used } \\
\text { TC and } 107 \\
\text { undergraduates used FC } \\
\text { (USA). }\end{array}$ & $\begin{array}{l}\text { A History survey course on } \\
\text { the U.S. History: } \\
\text { 1877-present ( } 1 \text { semester). }\end{array}$ \\
\hline $\begin{array}{l}\text { Murphree } \\
\text { [13] }\end{array}$ & $\begin{array}{l}107 \text { undergraduates used } \\
\text { FC and } 49 \\
\text { undergraduates used FC } \\
\text { with writing consultant } \\
\text { (USA). }\end{array}$ & Same as Murphree [2]. \\
\hline $\begin{array}{l}\text { Snyder et al. } \\
{[14]}\end{array}$ & $\begin{array}{l}\text { A total of } 209 \text { ninth } \\
\text { graders from three } \\
\text { cohorts used FC (USA). }\end{array}$ & $\begin{array}{l}\text { A World History course for } \\
\text { tenth grade New York State } \\
\text { Regents exam ( } 1 \text { year). }\end{array}$ \\
\hline $\begin{array}{l}\text { Westermann } \\
{[15]}\end{array}$ & $\begin{array}{l}26 \text { undergraduates used } \\
\text { FC (USA). }\end{array}$ & $\begin{array}{l}\text { A History course on the rise } \\
\text { of fascism in Europe during } \\
\text { the interwar period: } \\
1919-1939 \text { ( } 1 \text { semester). }\end{array}$ \\
\hline
\end{tabular}

For the research methods, all studies used self-reported survey to investigate student perceptions of the instructional approach. Only the two studies of Murphree [2], [13] examined student learning outcomes by objective measures (i.e., course grade and test scores).

The interventions and findings of these studies are organized and presented in four main themes: (a) The design of flipped classroom; (b) the effects of flipped classroom; (c) participants' perceptions of benefits and challenges of flipped classroom; and (d) the limitations of the reviewed studies.

\section{A. The Design of Flipped Classroom}

Among the reviewed studies, only Westermann [15] utilized an established framework, namely Bloom's taxonomy [16], to guide his design of flipped classroom. For the out-of-class learning component, the learning objectives focused on the lower levels of cognitive work such as gaining knowledge and comprehension. With the support of teacher 
and peers, the in-class learning objectives were then targeted at the higher levels of Bloom's taxonomy (i.e., application, analysis, synthesis, and evaluation).

Besides the learning objectives, the learning activities of History flipped classrooms were analyzed (Table III). For the out-of-class learning activities, all the History teachers emphasized the use of text-based materials. In particular, primary sources (e.g., letters, artifacts, and photographs) were delivered through a learning management system such as Blackboard [12], [15]. In Murphree's practice [2], [13], he would make use of an online database, called "The Trans-Atlantic Slave Trade Database," which has gathered various resources for teaching and learning. To facilitate student learning, Gaughan [12] and Snyder, Paska, and Besozzi [14] further prepared instructional videos to explain the learning materials together with relevant examples. In addition, some of the History teachers [2], [13], [15] utilized an online discussion forum, in which three purposes were identified:

1) Student practices: Students composed a short writing on the forum to answer teacher's questions [2], [13], [15];

2) Peer interactions: Through reading and responding the forum posts of classmates, student-to-student interaction was promoted [2], [13], [15]; and

3) Assessment for learning: From the forum posts, teacher could monitor student learning and provide individual feedback. During the face-to-face lesson, teacher could further clarify any misunderstandings and offer learning activities based on students' performance [2], [13], [15].

TABLE III: LEARNING ACTIVITIES IN HISTORY FLIPPED CLASSROOM

\begin{tabular}{|c|c|c|}
\hline Study & Out-of-class learning & In-class learning \\
\hline Gaughan [12] & $\begin{array}{l}\text { Video lecture, readings, } \\
\text { writing assignments. } \\
\text { Online database, online }\end{array}$ & $\begin{array}{l}\text { Brief review, poll, group } \\
\text { discussion, presentation. }\end{array}$ \\
\hline Murphree [2] & $\begin{array}{l}\text { MC quizzes, low-stakes } \\
\text { and high-stakes writing } \\
\text { assignments, online } \\
\text { discussion. }\end{array}$ & $\begin{array}{l}\text { Introduction to class } \\
\text { activities, class discussion, } \\
\text { writing tasks. }\end{array}$ \\
\hline $\begin{array}{l}\text { Murphree } \\
\text { [13] }\end{array}$ & $\begin{array}{l}\text { Same as Murphree [2]; } \\
\text { for the flipped classroom } \\
\text { with writing consultant, a } \\
\text { student assistant offered } \\
\text { office hours for student } \\
\text { appointments. }\end{array}$ & $\begin{array}{l}\text { Same as Murphree [2]; for } \\
\text { the flipped classroom with } \\
\text { writing consultant, a } \\
\text { student assistant was } \\
\text { available to offer supports. }\end{array}$ \\
\hline $\begin{array}{l}\text { Snyder et al. } \\
{[14]}\end{array}$ & $\begin{array}{l}\text { Video lecture, notes } \\
\text { taking. }\end{array}$ & $\begin{array}{l}\text { Brief review, group work, } \\
\text { presentation, class } \\
\text { discussion, inquiry-based } \\
\text { learning. }\end{array}$ \\
\hline $\begin{array}{l}\text { Westermann } \\
{[15]}\end{array}$ & $\begin{array}{l}\text { Readings, online } \\
\text { discussion. }\end{array}$ & $\begin{array}{l}\text { Group discussion, } \\
\text { presentation, writing tasks. }\end{array}$ \\
\hline
\end{tabular}

As for the in-class learning activities, History teachers aimed to create a student-centered learning environment [14], [15]. Some teachers would begin their lesson with an introduction to class activities [2], [12], [13] or a brief review [14] to recall students' memory of their out-of-class learning. After that, students would take part in group discussion [12], [15] or class-wide discussion [2], [13], [14]. The discussion was related to the online learning materials. Students might be required to share their insights [14], [15], offer critiques or further elaborate their arguments [12]. Finally, part of the in-class time was spent on doing writing tasks. Students could seek for the support of teacher [2], [13] and peers [15] when necessary. The student presentation and in-class writing tasks not only provided students with a chance to apply their knowledge and practice their skills [2], [13], but also enabled the teacher to assess student learning [15].

\section{B. The Effects of Flipped Classroom}

Among the five reviewed articles, only the two studies of Murphree [2], [13] assessed students' objective learning outcomes. In his studies, a total of three different instructional approaches were utilized and compared by using students' overall average scores and pre-test-post-test results. As summarized in Table IV, the students in flipped classroom with writing consultant scored the highest (81.1) among the three groups. But in terms of Historical knowledge, there was a greatest learning gain $(+13 \%)$ in the flipped classroom group. However, no statistical tests (e.g., t-test or ANOVA) were employed to examine whether the differences were significant or not.

TABLE IV: LEARNING OUTCOMES FROM DIFFERENT APPROACHES [2], [13]

\begin{tabular}{lll}
\hline \hline Instructional approach & $\begin{array}{l}\text { Students' overall } \\
\text { average score }\end{array}$ & $\begin{array}{l}\text { Pre-test-post-test on } \\
\text { Historical knowledge }\end{array}$ \\
\hline Traditional classroom & 74.1 & Data not available \\
$\begin{array}{l}\text { Flipped classroom } \\
\text { Flipped classroom with }\end{array}$ & 79.7 & $+13 \%$ \\
writing consultant & 81.1 & $+8 \%$ \\
\hline \hline
\end{tabular}

\section{Participants' Perceptions of Flipped Classroom: Benefits and Challenges}

Student perceptions of the History flipped classrooms were generally positive. For example, almost $90 \%$ of Murphree's [2] students would prefer taking a flipped History course; all students agreed or strongly agreed that Westermann [15] had utilized a student-centered approach in his History flipped classroom.

Based on the responses of student surveys and the comments of History teachers, three advantages of flipped classroom were identified:

1) Students were better able to prepare for lesson [12], [15] since some learning materials such as primary sources were delivered before class and explained through instructional videos [12], [14];

2) Teachers could monitor student learning through online forum posts [15], online quizzes [2], student presentation [12], [15], and in-class writing tasks [2], [13], [15]. Feedback could be provided accordingly; and

3) Flipped classroom facilitated student-to-student and teacher-to-student collaboration in both online and in-class environments [15]. As students could read and response to the forum posts of their classmates [2], [13], [15], peer interactions were initiated. By preparing students before class, more in-class time could be spent on peer communication (e.g., group discussion), collaboration (e.g., group work) [14], as well as the dialogue and interaction between teacher and students [12].

Despite the above benefits, the implementation of History flipped classroom was not without challenges. First, some 
students were not well-prepared for the class. Gaughan [12] reported that most of his students did not take notes when watching the instructional videos. Some even skipped the pre-class activities. Second, flipped classroom demanded teachers' considerable amount of start-up and maintenance efforts. For example, several hours might be required to prepare a short instructional video [14]. Also, teachers had to revise the videos and other learning materials whenever new information arose [12]. Third, some students may have difficulties in accessing the Internet and thus the flipped learning materials [14].

Table V summarizes the major benefits and challenges of History flipped classroom in the reviewed studies.

TABLE V: BENEFITS AND CHALLENGES OF HISTORY FLIPPED CLASSROOM

\begin{tabular}{|c|c|c|}
\hline Study & Benefits & Challenges \\
\hline Gaughan [12] & $\begin{array}{l}\text { Watching instructional } \\
\text { videos helped students } \\
\text { prepare for lesson. Students } \\
\text { recognized that in-class } \\
\text { discussion facilitated their } \\
\text { learning. }\end{array}$ & $\begin{array}{l}\text { Some students did not } \\
\text { watch the instructional } \\
\text { videos especially for } \\
\text { the longer one. Most of } \\
\text { the students did not } \\
\text { take notes when } \\
\text { watching the videos. }\end{array}$ \\
\hline Murphree [2] & $\begin{array}{l}\text { In-class writing tasks } \\
\text { improved students' } \\
\text { understanding of course } \\
\text { content and ability of writing. }\end{array}$ & $\begin{array}{l}\text { About half of the } \\
\text { students perceived that } \\
\text { online discussion } \\
\text { posting was the least } \\
\text { effective writing task. }\end{array}$ \\
\hline $\begin{array}{l}\text { Murphree } \\
\text { [13] }\end{array}$ & $\begin{array}{l}\text { FC promoted student } \\
\text { engagement, application of } \\
\text { skills, and understanding of } \\
\text { History content. More } \\
\text { in-class time could be spent } \\
\text { on writing exercises. }\end{array}$ & $\begin{array}{l}\text { Students were not } \\
\text { motivated to seek for } \\
\text { the help of writing } \\
\text { consultant. }\end{array}$ \\
\hline $\begin{array}{l}\text { Snyder et al. } \\
{[14]}\end{array}$ & $\begin{array}{l}\text { FC promoted student } \\
\text { engagement and improved } \\
\text { their technological skills. It } \\
\text { also catered to the needs of } \\
\text { diverse learners. Instructional } \\
\text { videos (screencasts) } \\
\text { facilitated student learning. }\end{array}$ & $\begin{array}{l}\text { Considerable efforts } \\
\text { were required to create } \\
\text { screencasts. The } \\
\text { videos were not } \\
\text { interesting to students. } \\
\text { Some students may be } \\
\text { lack of access to the } \\
\text { Internet. }\end{array}$ \\
\hline $\begin{array}{l}\text { Westermann } \\
{[15]}\end{array}$ & $\begin{array}{l}\text { Delivering primary sources } \\
\text { before class prepared students } \\
\text { for in-class activities. FC } \\
\text { facilitated student-to-student } \\
\text { and teacher-to-student } \\
\text { collaboration in both online } \\
\text { and in-class environments. }\end{array}$ & Not mentioned \\
\hline
\end{tabular}

FC = Flipped classroom

\section{The Limitations of the Reviewed Studies}

The reviewed studies investigated the use of flipped classroom in History education contexts. Except the two studies of Murphree [2], [13], other researchers conducted their study without a control group. Although within group studies have their value, it is unclear how the learning gain and student perceptions of flipped classroom are related to other non-flipped learning environments.

Some studies employed self-reported measures (e.g., student survey) to investigate student perceived learning. Results from these self-reported studies suggested that History flipped classroom could enhance student learning. For example, $80 \%$ of Gaughan's [12] students reported that they had learned a lot from the flipped History course. However, Sim and Hew [17] pointed out that the self-reported data should be viewed with caution since participants may provide socially desirable answers and pretend to be good. Whether History flipped classroom can really improve student learning remains unanswered without using some objective measures such as tests.

As for the comparison studies of Murphree [2], [13], the average scores of the two flipped classroom groups appeared to be higher than that of the traditional classroom (Table IV). However, drawing conclusion without a statistical test (e.g., ANOVA) may not be rigorous enough to claim the superiority of flipped classroom over traditional classroom.

Finally, the duration of the reviewed studies was short (e.g., one semester) in general. While the positive results could come from flipped classroom, other factors could have been involved. For example, a novelty effect may result in a short-term boost to student perceptions and their learning outcomes [18].

\section{DISCUSSION}

The aim of this paper is to propose an instructional model of History flipped classroom. In Westermann's [15] study, Bloom's taxonomy [16] was employed as a framework to design his flipped History course. While Bloom's taxonomy can provide a guideline on setting educational objectives for the two components of flipped classroom (i.e., out-of-class and in-class component), this framework appears to be inadequate to inform the flow of teaching and learning.

The following sessions discuss adopting the $5 \mathrm{E}$ instructional model [19] to design a History flipped classroom. Based on the reviewed studies and the existing literature, the design of out-of-class and in-class learning activities are elaborated. Finally, the challenges of implementing History flipped classroom are discussed and some recommendations are proposed.

\section{A. 5E Instructional Model and Flipped Classroom}

In the reviewed studies, History teachers provided students with various teaching and learning activities. These activities can be organized into the framework of $5 \mathrm{E}$ instructional model [19]. This model is derived from various instructional theories and models such as Herbart's instructional model [20], Dewey's instructional model [21], Heiss, Obourn, and Hoffman Learning Cycle [22], and Atkin-Karplus Learning Cycle [23]. In this model, an instructional sequence is proposed for course design or lesson planning.

The instructional sequence of $5 \mathrm{E}$ instructional model consists of five phases, including engagement, exploration, explanation, elaboration, and evaluation (Table VI). The engagement phase suggests that teachers should first promote students' curiosity and recall the prerequisite knowledge required for learning the new topic. Then in the exploration phase, students should explore the learning items through activities, aiming at establishing a foundation of learning. Followed by the explanation phase, teachers should demonstrate the new knowledge or skills to their students. After that, the elaboration phase encourages students to solve novel problems by applying what they have learned in 
previous phases. Finally, students should assess their own understanding and ability. Meanwhile, teachers should evaluate students' learning progress and their learning outcomes.

TABLE VI: SUMMARY OF THE 5E INSTRUCTIONAL MODEL

\begin{tabular}{ll}
\hline \hline Phase & Description \\
\hline Engagement & $\begin{array}{l}\text { Teachers use learning activities to promote students' } \\
\text { curiosity and activate their prior knowledge required for } \\
\text { learning the new topic. }\end{array}$ \\
Exploration & $\begin{array}{l}\text { Students gain experiences related to the learning items } \\
\text { through activities such as preliminary investigations. } \\
\text { Based on students' experiences in the engagement and } \\
\text { exploration phase, teachers introduce the new } \\
\text { knowledge and skills to their students. } \\
\text { Teachers reinforce students' understanding and improve } \\
\text { their skills by offering additional activities. Students } \\
\text { have to apply what they have learned to solve novel } \\
\text { problems. }\end{array}$ \\
Students assess their own understanding and ability. \\
Meanwhile, teachers evaluate students' learning \\
Evaluation \\
progress and their learning outcomes.
\end{tabular}

Outside the contexts of flipped classroom, the effectiveness of $5 \mathrm{E}$ instructional model has been extensively researched and supported by empirical studies. Specifically, this model has a positive effect on students' mastery of subject matter, scientific reasoning, interest and attitude [19].

Recently, a few studies utilize the 5E instructional model to guide their design of flipped classroom (Table VII). For example, in their Biology course, Jensen, Kummer, and Godoy [24] delivered the engagement, exploration, and explanation phase outside the classroom. The in-class time then focused on the elaboration and evaluation phase. In Svensson and Adawi's [25] Engineering course, the design was similar to Jensen et al.'s [24] flipped classroom, except that the exploration phase of the former study was conducted inside the classroom.

TABLE VII: THE USE OF 5E InSTRUCTIONAL MODEL IN RECENT FLIPPED ClassRoom StUdies

\begin{tabular}{lll}
\hline \hline Phase & Jensen et al. [24] & Svensson and Adawi [25] \\
\hline Engagement & Out-of-class & Out-of-class \\
Exploration & Out-of-class & Out-of-class \\
Explanation & Out-of-class & In-class \\
Elaboration & In-class & In-class \\
Evaluation & In-class & In-class \\
\hline \hline
\end{tabular}

The 5E instructional model can provide History teachers with a holistic framework of flipped classroom design. Through the lens of this model, all the activities of History flipped classroom can be categorized into one of the five instructional phases. Table VIII shows that the engagement and evaluation phase were performed both outside and inside the classroom. For the engagement phase, teachers would promote student motivation not only by online instructional videos, but also by in-class activities such as poll [12] and brief review [12], [14]. Similarly, teachers would evaluate student learning in the online learning environment (e.g., online quizzes and forum posts) and the face-to-face classroom (e.g., student presentation and writing tasks). Hence, only the elaboration phase was skipped outside the classroom. As for the in-class learning component, the engagement phase was involved in addition to the elaboration and evaluation phase. Hence, a linear framework of $5 \mathrm{E}$ instructional model was unable to characterize the unique structure of History flipped classroom.

TABLE VIII: CLASSIFICATION OF FLIPPED ClASSROOM ACTIVITIES

\begin{tabular}{|c|c|c|}
\hline Phase & Out-of-class learning & In-class learning \\
\hline Engagement & $\begin{array}{l}\text { Teacher used multimedia } \\
\text { (e.g., videos) to engage } \\
\text { students [12], [14]. }\end{array}$ & $\begin{array}{l}\text { Teacher engaged } \\
\text { students by poll [12], } \\
\text { and recalled students' } \\
\text { out-of-class learning } \\
{[12],[14] .}\end{array}$ \\
\hline Exploration & $\begin{array}{l}\text { Students explored primary } \\
\text { sources [12], [15] or online } \\
\text { resources [2], [13]. }\end{array}$ & Nil \\
\hline Explanation & $\begin{array}{l}\text { Teacher introduced the } \\
\text { learning materials [12], [14]. }\end{array}$ & Nil \\
\hline Elaboration & Nil & $\begin{array}{l}\text { Students took part in } \\
\text { class discussion [14], } \\
\text { offered critiques and } \\
\text { elaborated arguments } \\
\text { [12], [15], and worked } \\
\text { on writing tasks [2], } \\
\text { [13], [15]. }\end{array}$ \\
\hline Evaluation & $\begin{array}{l}\text { Teacher checked online } \\
\text { quizzes responses [2], [13]; } \\
\text { students commented on } \\
\text { classmates' forum posts [15]; } \\
\text { and teacher provided } \\
\text { feedback on students' forum } \\
\text { posts [15]. }\end{array}$ & $\begin{array}{l}\text { Teacher assessed } \\
\text { student learning } \\
\text { through student } \\
\text { presentation [15], and } \\
\text { provided feedback on } \\
\text { students' writing tasks } \\
\text { [2], [13]. }\end{array}$ \\
\hline
\end{tabular}

Taken together the learning activities used in the reviewed studies, I propose a cyclic model that performed the engagement, exploration, explanation, and evaluation phase outside the classroom. Then the main focus of in-class learning should be the elaboration and evaluation phase [24]. Nevertheless, the engagement phase is still necessary inside the classroom. Figure 2 shows a graphical representation of the $5 \mathrm{E}$ flipped classroom instructional model.

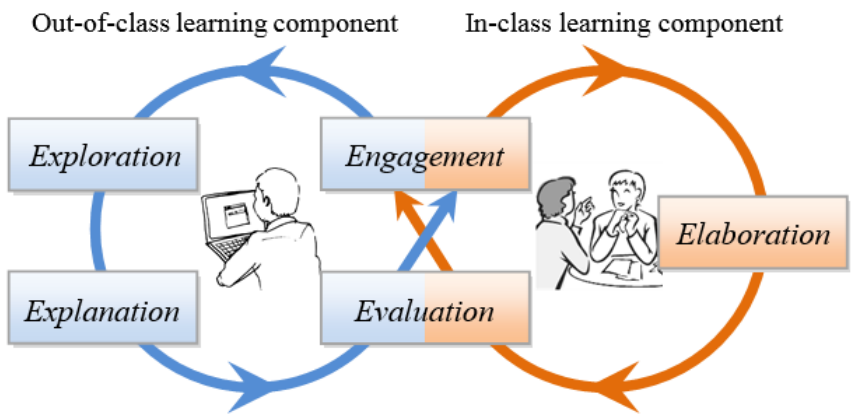

Fig. 2. 5E flipped classroom instructional model.

\section{B. Design of Out-of-Class Learning Activities}

Fig. 3 outlines the out-of-class learning activities of History flipped classroom. Teachers have to promote students' curiosity and activate their prior knowledge in the engagement phase. Instead of leaving students' exploration unguided outside the classroom, teachers should explain the learning materials (e.g., introduce the contexts of primary sources) to their students. Through the explanation phase, students' ability to comprehend the materials will be promoted [12]. Finally, teachers should evaluate students' 
out-of-class learning outcomes.

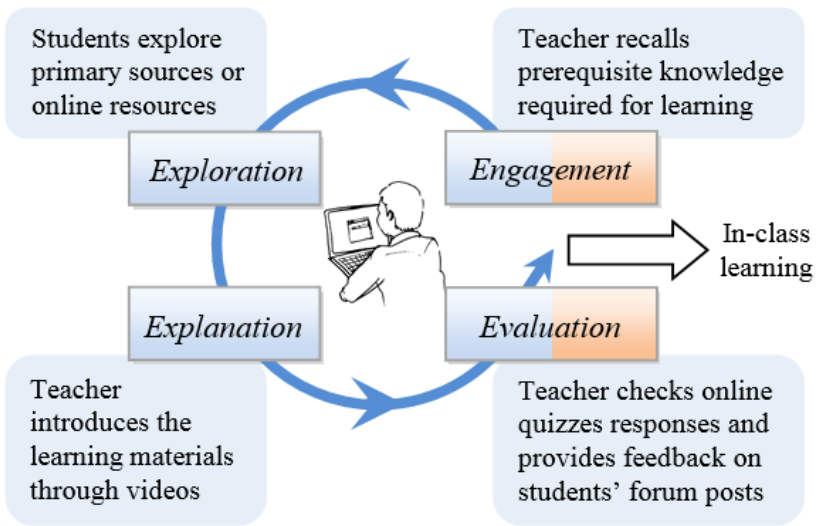

Fig. 3. Out-of-class learning activities in $5 \mathrm{E}$ flipped classroom.

In History flipped classroom, students can explore the primary sources like a Historian [12], [15]. Exploring text-based materials such as primary sources, readings, and online History database are the core learning activities for class preparation. This exploration phase starts a process of inquiry [15] and equips students with the necessary background knowledge for in-class learning activities such as discussion [12].

While teachers should upload the entire set of materials online, too much information may overwhelm students and become a barrier of retrieving the relevant resources [26]. Considering the practices of some flipped classroom practitioners, teachers can organize the resources by lesson or by chapter [27], and provide instructions to locate the pre-class learning materials [12].

In order to engage students in the exploration activities, teachers are encouraged to use videos for revision and explanation [12], [14]. Regarding the concerns raised in the reviewed studies, Mayer's [28] design principles of multimedia learning should be used to guide the production of instructional videos (Table IX).

First, some students did not watch the instructional videos because of the duration [12]. In fact, Mayer [28] pointed out that a long video should be divided into a series of short videos (Segmenting principle). Specifically, Guo, Kim, and Rubin [29] found that the ideal length of an instructional video should not exceed six minutes. However, six-minute time may not be enough for History teachers to articulate a learning unit. Based on the experiences of Snyder et al. [14] and Gaughan [12], teachers may consider limiting each video within 12 minutes for secondary school students and 15 minutes for university students.

Second, some students did not write down any important points during the online lecture [12]. To guide students' notes taking, Snyder et al. [14] used "ScreenFlow" software to produce PowerPoint embedded instructional videos. Teachers may also consider using "Office Mix" which is a free add-in of MS PowerPoint for creating PowerPoint presentation videos. In addition to texts and images, Office Mix enables free-hand writings on the slides. Teachers can thus highlight the essential materials by underlining or using arrows (Signaling principle) to draw students' attention and cue notes taking.

Third, few students of Snyder et al. [14] complained that the instructional videos were boring. They perceived that the teacher in the video was just reading facts rather than talking to them. In fact, Mayer [28] found that students can learn more through the videos in a conversational style when compared with a formal style (Personalization principle). Therefore, teachers should use the conversational wordings such as "I" and "you" to promote a sense of social presence in the video recordings.

\begin{tabular}{lll} 
TABLE IX: MAYER's [26] DESIGN PRINCIPLES OF MULTIMEDIA LEARNING \\
\hline \hline Principle & Description & Problem addressed \\
\hline Segmenting & $\begin{array}{l}\text { Breaking a long video into } \\
\text { a series of short videos. } \\
\text { Drawing students' }\end{array}$ & $\begin{array}{l}\text { Students did not prefer } \\
\text { lengthy videos [12]. }\end{array}$ \\
& $\begin{array}{l}\text { attention to the essential } \\
\text { materials by cues (e.g., } \\
\text { underline and voice } \\
\text { emphasis on words). }\end{array}$ & $\begin{array}{l}\text { Students did not take } \\
\text { notes when watching } \\
\text { the videos [12]. }\end{array}$ \\
& $\begin{array}{l}\text { Putting words in a } \\
\text { conversational style (e.g., } \\
\text { "I" and “you") with }\end{array}$ & $\begin{array}{l}\text { Students liked } \\
\text { teacher's talking } \\
\text { instead of just listening } \\
\text { students instead of a formal } \\
\text { style. }\end{array}$ \\
\hline \hline
\end{tabular}

After the exploration and explanation phase, a short follow-up quiz such as Murphree's [2], [13] $10 \mathrm{MC}$ questions in 10 minutes can be provided. The quiz not only serves as a "gate-check" to ensure students' preparation for the class [30], but also provides information on students' mastery of learning outside the classroom. Based on their quiz performance, teachers can re-teach the part with poor scores during face-to-face class meetings.

Finally, an online discussion forum can be used as a platform for peer interactions [15]. For example, in Murphree's [2], [13] and Westermann's [15] flipped History courses, students were required to complete and post a short writing task to the forum before the class. Their classmates could response to the posts. Blankenship [31] pointed out that this kind of communication could strengthen students' reasoning skill and promote their engagement in historical inquiry. At the same time, teachers can interact with students through the forum. In Westermann's [15] practice, he would assess student learning through the forum posts and provide immediate feedback accordingly. During the in-class time, teachers can further discuss their forum posts so that the students can have a better understanding of the topic [2], [13].

\section{Design of In-class Learning Activities}

Figure 4 outlines the in-class learning activities of History flipped classroom. In the engagement phase, teachers have to provide feedback on students' quiz performance and their forum posts. Also, teachers should recall students' out-of-class learning (e.g., primary sources) in order to prepare them for the in-class activities [12]. Group discussion and in-class writing tasks provide a chance for students to offer critiques and elaborate their own arguments. They can also apply their new knowledge and skills to handle some novel problems. Finally, teachers can evaluation student learning based on their presentation and in-class writing tasks.

To promote student interest of in-class activities, Gaughan [12] used questions and polls in his History flipped classroom. In view of the large class size, he suggested using a classroom 
response system, namely "iClicker," to collect students' in-class responses. To answer teachers' questions, students have to install a mobile application on their mobile devices. However, some teachers may not want to rely on students' mobile devices. "Plickers" is another tool that can collect students' responses without involving students' mobile devices. Students can use a printed Plickers card to show their answer. By scanning the cards through a phone camera with the Plickers apps, teachers can get students' answers.

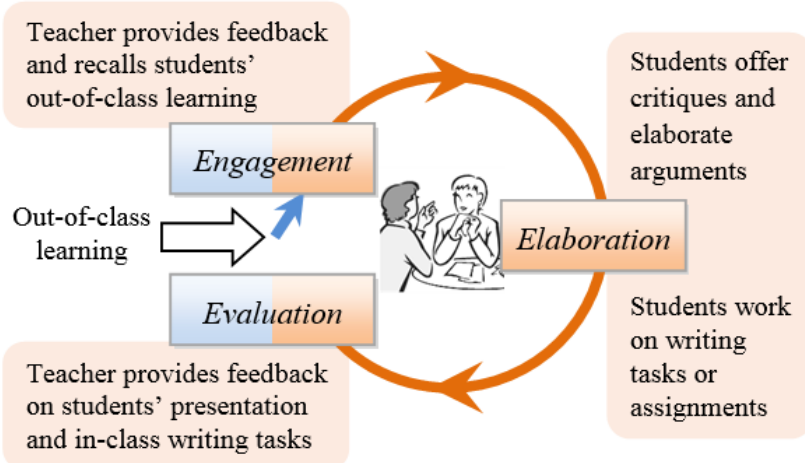

Fig. 4. In-class learning activities in 5E flipped classroom.

As the core in-class activities of History flipped classroom, students can interpret and discuss the meaning of primary sources like a Historian [12]. Group discussion provides a platform for students to share their insights, response to others offer critiques, and elaborate their own arguments. However, poor design of group activities in History lessons would result in students' disengagement such as off-task behavior and free-rider problem [32], especially when more in-class time is available in flipped classroom. So how can we design the small group activities in History flipped classrooms?

First, teachers can assign some talkative students in each pair or group to facilitate group dynamics [12]. Second, recent studies of flipped classroom (e.g., [33], [34]) incorporate think-pair-share approach into their group activity design. Think-pair-share is one of the cooperative learning approaches. In this approach, every student has to share with at least one of their classmates. This approach involves four steps [35]:

1) Question: Teacher poses a discussion question which involves higher level cognitive work [15] such as a compare-and-contrast analysis of two primary sources [2], [13];

2) Think: Students think independently about the question. Adequate time should be given for individual thinking and working out their own responses;

3) Pair: Students work in pair and discuss their answer. They can thus have an opportunity to response to peers' ideas and elaborate their own arguments; and

4) Share: Students take part in a class discussion and share their insights after the pair discussion. Further discussion is then promoted.

After the discussion, students should turn their ideas into a written format. As suggested by Murphree [2], [13], the in-class writing tasks aim to improve students' writing skills of applying historical interpretations. Teachers should encourage their students to ask questions about the content and writing.
To evaluate student learning progress and their learning outcomes, teachers can circulate among groups and listen to their conversations during the discussion. In this way, teachers will understand their students better [12]. After the discussion, students' presentation enables teachers to assess student learning outcomes [15]. Teachers can also evaluate their learning through the in-class writing tasks (e.g., interpretive ability related to historical content) [2], [13].

\section{Challenges and Recommendations}

Two practical concerns of implementing History flipped classroom were raised in the reviewed studies. First, preparing the flipped learning materials could be time consuming. In Snyder et al.'s [14] experience, a 10-minute instructional video might require an hour for production. However, it is not necessary to flip the whole course at once. Teachers can transform their traditional classroom to a flipped classroom at a reasonable pace. For example, flipped classroom practitioners can cumulate their flipped learning resources progressively by working on two to three topics every year.

Second, some students may have difficulties in accessing the Internet at home [14]. As a result, they cannot access the learning materials for class preparation. In this regard, some flipped classroom practitioners would reserve a few computer facilities on campus to support their implementation of flipped classroom [36]. The students without the Internet at home can prepare for the class at school. Also teachers may prepare flash drives or DVDs to deliver the out-of-class learning materials for these students [37].

\section{CONCLUSION AND FUTURE RESEARCH}

Now that the framework of History flipped classroom is somewhat solid with the support of the 5E instructional model. Subsequently, further research is required to examine its efficacy and discuss any challenges of using this instructional approach. Researchers could detail how they utilize the 5E flipped classroom model and the existing literature to guide their design of flipped classroom. Meanwhile, since there is a variety of History curriculum in different courses, it is necessary for the researchers to introduce the course (e.g., objectives and contents) involved in their study. The design of out-of-class and in-class learning activities together with the rationale behind should also be clearly described [4]. This information is crucial for other practitioners to determine whether the practices enacted are suitable for their own context.

In order to examine the effects of flipped classroom, the controlled experimental or quasi-experimental designs are recommended for future studies [4], [9]. In this way, student achievement in flipped classroom can be contrasted with that in other instructional approaches (e.g., traditional classroom). In case of single-group studies, researchers may consider using historical cohorts which utilized a non-flipped teaching approach for comparison. To minimize participant selection differences among groups (i.e., historical cohort control groups and experimental group), taking multiple historical cohorts into account is preferable [38]. Besides, understanding participants' experience can help evaluate each 
segment of flipped classroom. Therefore, qualitative work into students' perceptions and teachers' reflections are vitally important for further improvement [9].

Finally, researchers have to be open to the possibility that flipped classroom may not be suitable in every educational setting [9]. In view of the limited amount of flipped classroom research in History education, the effects and challenges of using History flipped classroom is yet to be explored. More empirical studies are thus recommended.

\section{REFERENCES}

[1] S. Joseph, "What are upper secondary school students saying about history?" Caribbean Curriculum, vol. 18, pp. 1-26, 2011.

[2] D. S. Murphree, "Writing wasn't stressed, accurate historical analysis was stressed: Student perceptions of in-class writing in the inverted, general education, university History survey course," History Teacher, vol. 47, no. 2, pp. 209-219, 2014.

[3] G. Boadu, "Effective teaching in history: The perspectives of history student-teachers," International Journal of Humanities and Social Science, vol. 3, no. 1, pp. 38-51, 2015.

[4] J. L. Bishop and M. A. Verleger, "The flipped classroom: A survey of the research," in Proc. ASEE National Conference Proceedings, Atlanta, GA, 2013.

[5] J. O'Flaherty and C. Phillips, "The use of flipped classrooms in higher education: A scoping review," Internet and Higher Education, vol. 25, pp. 85-95, 2015.

[6] J. S. M. Chua and F. Lateef, "The flipped classroom: Viewpoints in Asian universities," Education in Medicine Journal, vol. 6, no. 4, pp. 20-26, 2014

[7] V. Betihavas, H. Bridgman, R. Kornhaber, and M. Cross, "The evidence for 'flipping out': A systematic review of the flipped classroom in nursing education," Nurse Education Today, vol. 38, pp. $15-21,2016$

[8] J. Bergmann and A. Sams, "Remixing chemistry class," Learning and Leading with Technology, vol. 36, no. 4, pp. 24-27, 2008.

[9] L. Abeysekera and P. Dawson, "Motivation and cognitive load in the flipped classroom: Definition, rationale and a call for research," Higher Education Research and Development, vol. 34, no. 1, pp. 1-14, 2015.

[10] D. Moher, A. Liberati, J. Tetzlaff, and D. G. Altman, "Reprint-preferred reporting items for systematic reviews and meta-analyses: The PRISMA statement," Physical Therapy, vol. 89, no. 9, pp. 873-880, 2009.

[11] C. Wohlin, "Guidelines for snowballing in systematic literature studies and a replication in software engineering," in Proc. the 18th International Conference on Evaluation and Assessment in Software Engineering, ACM, May 2014.

[12] J. E. Gaughan, "The flipped classroom in world history," History Teacher, vol. 47, no. 2, pp. 221-244, 2014.

[13] D. Murphree, "Flipping the history classroom with an embedded writing consultant: Synthesizing inverted and WAC paradigms in a university history survey course," Social Studies, vol. 106, no. 5, pp. 218-225, 2015

[14] C. Snyder, L. M. Paska, and D. Besozzi, "Cast from the past: Using screencasting in the social studies classroom," The Social Studies, vol. 105, no. 6, pp. 310-314, 2014.

[15] E. B. Westermann, "A half-flipped classroom or an alternative approach?: Primary sources and blended learning," Educational Research Quarterly, vol. 38, no. 2, pp. 43-57, 2014.

[16] B. S. Bloom, Taxonomy of Educational Objectives: The Classification of Educational Goals, New York: Longman, 1956.

[17] J. W. S. Sim and K. F. Hew, "The use of weblogs in higher education settings: A review of empirical research," Educational Research Review, vol. 5, no. 2, pp. 151-163, 2010.
[18] F. J. Gravetter and L.-A. B. Forzano, Research Methods for the Behavioral Sciences, 4th ed. Belmont, CA: Wadsworth Cenage Learning, 2012, ch. 6, pp. 157-194.

[19] R. W. Bybee, J. A. Taylor, A. Gardner, P. Van Scotter, J. C. Powell, A. Westbrook, and N. Landes, The BSCS 5 E Instructional Model: Origins and Effectiveness, Colorado Springs, 2006.

[20] J. F. Herbart, Outlines of Educational Doctrine, New York: The Macmillan company, 1901.

[21] J. Dewey, How we Think, Boston: D.C. Heath \& Co. Publishers, 1910

[22] E. D. Heiss, E. S. Obourn, and C. W. Hoffman, Modern Science Teaching, New York: The Macmillan Company, 1950.

[23] J. M. Atkin and R. Karplus, "Discovery or invention?" The Science Teacher, vol. 29, no. 5, pp. 45-51, 1962.

[24] J. L. Jensen, T. A. Kummer, and P. D. D. M. Godoy, "Improvements from a flipped classroom may simply be the fruits of active learning," CBE-Life Sciences Education, vol. 14, no. 1, article 5, 2015.

[25] L. Svensson and T. Adawi, "Designing and evaluating a flipped signals and systems course," in Proceedings of the 14th European Conference on e-Learning - ECEL, pp. 584-591, October 29-30, 2015.

[26] G. S. Mason, T. R. Shuman, and K. E. Cook, "Comparing the effectiveness of an inverted classroom to a traditional classroom in an upper-division engineering course," IEEE Transactions on Education, vol. 56, no. 4 , pp. 430-435, 2013.

[27] T. M. Marcum and S. J. Perry, "Flips and flops: A new approach to a traditonal law course," Journal of Legal Studies Education, vol. 32, no. 2, pp. 255-286, 2015.

[28] R. E. Mayer, The Cambridge Handbook of Multimedia Learning, New York: Cambridge University Press, 2014.

[29] P. J. Guo, J. Kim, and R. Rubin, "How video production affects student engagement: An empirical study of MOOC videos," in Proc. the first ACM Conference on Learning@ Scale Conference, pp. 41-50, 2014.

[30] S. Zappe, R. Leicht, J. Messner, T. Litzinger, and H. W. Lee, "“Flipping" the classroom to explore active learning in a large undergraduate course," in Proceedings of 2009 ASEE Annual Conference \& Exposition, Austin, TX, 2009.

[31] W. Blankenship, "Making connections: Using online discussion forums to engage students in historical inquiry," Social Education, vol. 73, no. 3, pp. 127-130, 2009

[32] R. W. Maloy and I. LaRoche, "Student-centered teaching methods in the history classroom: Ideas, issues, and insights for new teachers," Social Studies Research and Practice, vol. 5, no. 2, pp. 46-61, 2010.

[33] A. B. Flynn, "Structure and evaluation of flipped chemistry courses: Organic \& spectroscopy, large and small, first to third year, English and French," Chemistry Education Research and Practice, vol. 16, no. 2, pp. 198-211, 2015.

[34] J. E. McLaughlin, L. M. Griffin, D. A. Esserman, C. A. Davidson, D. M. Glatt, M. T. Roth, N. Gharkholonarehe, and R. J. Mumper, "Pharmacy student engagement, performance, and perception in a flipped satellite classroom," American Journal of Pharmaceutical Education, vol. 77, no. 9, article 196, 2013.

[35] M. A. Gunter, T. H. Estes, and J. H. Schwab, Instruction: A models approach, 4th ed. Boston: Allyn and Bacon, 2003.

[36] M. J. Lage, G. J. Platt, and M. Treglia, "Inverting the classroom: A gateway to creating an inclusive learning environment," The Journal of Economic Education, vol. 31, no. 1, pp. 30-43, 2000

[37] K. R. Clark, "The effects of the flipped model of instruction on student engagement and performance in the secondary mathematics classroom," Journal of Educators Online, vol. 12, no. 1, pp. 91-115, 2015.

[38] T. M. Walser. (June 2014). Quasi-experiments in schools: The case for historical cohort control groups. Practical Assessment, Research \& Evaluation. [Online]. 19(6). Available: http://pareonline.net/getvn.asp?v=19\&n=6

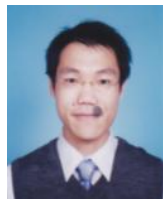

Chung Kwan Lo is an EdD student of the Faculty of Education, The University of Hong Kong. His main research interests are flipped classroom, collaborative learning, and technology-enhanced learning. 